\title{
KOMUNIKATY
}

\section{Maciej Bala}

(Uniwersytet im. A. Mickiewicza w Poznaniu, Poznań - Polska)

\section{UKRAINA W PROGRAMIE PARTII NARODOWO-BOLSZEWICKIEJ EDUARDA LIMONOWA}

W polskiej opinii publicznej powszechne jest postrzeganie wszelkich opozycyjnych wobec autorytarnych rządów prezydenta Władimira Putina partii, jako zwolenników demokracji. Temu nie do końca prawdziwemu poglądowi wymyka się Partia Narodowo-Bolszewicka założona przez pisarza Edwarda Limonowa i filozofa Aleksandra Dugina. Swojego czasu, stanowiła ona dość barwny element rosyjskiej sceny politycznej oraz należała do najaktywniejszych i najbardziej nieprzejednanych antagonistów wobec rządów Władimira Putina. Pomimo deklaracji niekwestionowanego przywódcy i założyciela partii, Edwarda Limonowa, iż po zwrocie ideologicznym w roku 2004 partia będzie popierać rozwój spoleczeństwa obywatelskiego $\mathrm{w}$ Rosji ${ }^{1}$ zaznaczono, iż wcześniejszy program NBP z roku 1994 pozostaje nadal aktualny. To stanowisko formalnie zatwierdzono w tzw. Programie minimum w 2004 roku. Jest to o tyle niepokojące, iż we wspomnianym pierwszym programie jawnie odwoływano się do działań nie mających z demokracją nic wspólnego. Nie zmieniono także symboliki partii, jedną z nich jest sam sztandar Partii NarodowoBolszewickiej będącym skrzyżowaniem czarnego młota i sierpa $\mathrm{w}$ białym kręgu na czerwonym tle. Skojarzenia z symboliką dawnego Związku Radzieckiego i III Rzeszy są jednoznaczne, jednocześnie szeregowi członkowie partii zaprzeczają wszelkim odniesieniom partii do potępionych ideologii.

Partia Narodowo-bolszewicka pod przewodnictwem kontrowersyjnego pisarza Eduarda Limonowa i filozofa Aleksandra Dugina, najczęściej była kojarzona z kontrowersyjną ideologią i specyficznymi formami protestów politycznych. Sama ideologia partii jest swoistym konglomeratem różnorodnych prądów politycznych, począwszy od rosyjskiego

\footnotetext{
${ }^{1}$ Программа минимум, „, Российская газета", 19.01.2005.
} 
nacjonalizmu, poprzez eurazjatyzm z wyraźnymi elementami geopolity$\mathrm{ki}$, na radykalnej lewicy skończywszy. Nieodłącznym elementem ideologii partii jest kontestacja rozmaitych prądów kontrkulturowych i zachwyt nad estetyką punk-rocka. Dany element ideologii, oraz łatwość w łączeniu przeciwstawnych sobie prądów politycznych wyróżnia Partię Narodowo-Bolszewicką od pozostałych partii tak i z prawej, jak i z lewej strony rosyjskiej sceny politycznej.

Zwolennicy Eduarda Limonowa zwracają uwagę na położenie ludności rosyjskojęzycznej, która po rozpadzie Związku Radzieckiego znalazła się poza granicami Rosji. Ich zdaniem, owa ludność jest brutalnie dyskryminowana przez władze nowopowstałych państw, w szczególności na Ukrainie, która dla zwolenników Limonowa jest przedmiotem drwin i pogardy. Narodowi bolszewicy nie uznają aktu likwidacji sowieckiego imperium i w konsekwencji, sytuacji politycznej ukształtowanej w wyniku tego aktu. Narodowi bolszewicy, szczególną uwagę zwracają na status ludności rosyjskojęzycznej na Ukrainie i na wydarzeniach na Ukrainie podczas pomarańczowej rewolucji w 2004 roku.

Jedną z pierwszych akcji bezpośrednich, przeprowadzoną przez narodowych bolszewików, była akcja w Sewastopolu na Krymie 24 sierpnia 1999 roku. Polegała ona na zabarykadowaniu się w wieży Klubu Morskiego i rozwieszeniu rosyjskiej flagi i transparentu z napisem: „Sewastopol-miastem rosyjskim!"”. Rozrzucano również ulotki oraz egzemplarze partyjnej gazety. Blokadę wieży zlikwidowano po wspólnej akcji ukraińskiej milicji i rosyjskich żołnierzy piechoty morskiej. Narodowi bolszewicy na łamach partyjnej gazety nie kryli swojego oburzenia zachowaniem rosyjskich żołnierzy.

Narodowi bolszewicy zajmowali identyczne stanowisko wobec Ukrainy podczas tzw. Pomarańczowej rewolucji, jednakże, z uznaniem wypowiadali się na temat postawy zwolenników Wiktora Juszczenki, podziwiali ich zaangażowanie i entuzjazm. Sytuację na Ukrainie postrzegali jako pretekst mający na celu osłabienie pozycji politycznej, głównego antagonisty narodowych bolszewików, prezydenta Władimira Putina, bowiem nie uznawali oni jego autorytarnych rządów. Sprzeciw wobec władzy prezydenta, stanowi konsekwencję zmiany programu politycznego w 2004 roku. Kładziono w nim nacisk m.in. na poszanowanie swobód obywatelskich. Jednak, szacunek wobec zwolenników Wiktora Juszczenki, rezygnacja $z$ haseł pro totalitarnych, wcale nie oznaczał zmiany nastawienia wobec państwa ukraińskiego, względem którego używano niekiedy niestosownego słownictwa.

Partia Narodowo-Bolszewicka została zdelegalizowana w 2005 ro$\mathrm{ku}$, pomimo tego zwolennicy Edwarda Limonowa, zapewniają, iż nie zaprzestaną swojej działalności i nadal będą dążyć do zmiany sytuacji 
politycznej w Rosji. Sam były lider partii Eduard Limonow jest przekonany, iż prędzej czy później rosyjska scena polityczna ulegnie zmianie. Według niego, skoro w państwach arabskich w 2011 roku nastąpiły niespodziewane przeobrażenia polityczne, to dany proces nie ominie również Rosji pod rządami Władimira Putina. 
